\title{
Seven Challenges for EU Administrative Law
}

\author{
Prof. Dr. Herwig C.H. Hofmann ${ }^{\mathrm{I}}$ \\ Professor of European and Transnational Public Law and Director of the Centre for \\ European Law at the University of Luxembourg
}

\begin{abstract}
This contribution has the objective to reflect on existing and impending challenges to EU public law from an administrative perspective. This will be undertaken against the fast-paced developments of the past 50 years linking various levels of government and administration in the Member States and the EU to administrative networks which are active also on the international scene. In this context, European administrative law has grown and evolved and has become an important, yet often not very fully understood, factor shaping the reality of policy implementation in the EU.
\end{abstract}

\section{An Administrative Perspective on EU Law - Changing Perspectives of EU Administrative Law}

European integration through law is highly dynamic process. This paper makes an attempt to contribute to the thinking about EU public law by contextualising and giving an overview of some of the central aspects of the evolving scholarship necessary to tackle the challenges to the EU's future as a legal system from an administrative law perspective.

After an initial flourishing in legal literature and case law in the founding period of the European integration process, especially in the context of the ECSC, administrative law virtually disappeared from the horizon of EU legal scholars. The initial administrative perspective on European integration was a rather restricted and even tendentious one. In the context of the original EEC it was often associated more with the aim of denying the 'state' quality of the $\mathrm{E}(\mathrm{E}) \mathrm{C}$ than of attempting to encompass the real nature of legal relations within the early European Communities. ${ }^{2}$ The disappearance of this administrative perspective can be largely traced to the interest

I herwig.hofmann@uni.lu This paper is a footnoted version of a presentation I gave at the First REALaw research conference in Groningen on June 3, 2009. I would like to especially thank Gerard Rowe for investing much of his time into developing and clarifying the ideas contained in this article. Many others have generously contributed their time to discussing the ideas therein.

2 This came to be known under the idea of the Communities being the Member States' special purpose vehicle or ,Zweckverband' for achieving certain limited policy goals. See for example H.P. Ipsen, Zur Exekutivrechtsetzung in der Europäischen Gemeinschaft, in: P. Badura, R. Scholz (eds.), Wege und Verfahren des Verfassungslebens (Beck Verlag, München, I993), 425-44I. 
in the 'constitutionalisation' of the $\mathrm{E}(\mathrm{E}) \mathrm{C}$ legal system. 'Constitutionalists' provided for a change of focus looking at the specific nature of the E(E)C and later the EU in relation to the Member State legal orders and the role of the individual vis-à-vis the various levels. 3 This often resulted in a multilevel understanding of the EU inspired by federal structures. A simplified version of such an approach might read as follows: Member States delegate certain rule-making powers to the EU which the latter exercises according to pre-defined procedures and types of regulatory action. These regulatory actions emanating from the European level are in turn implemented by the Member States. ${ }^{4}$ Additionally, this vision of EU law saw the EU having the power to act externally within a system of public international law. Under such a model, disputes between the different levels could be solved through complex 'conflict of laws' arrangements establishing the relation between EU law and national law as well as the relation between public international law and the law of the EU. Such federal-constitutionalist thinking carries, in my view, the risk of developing a mental picture involving clear delegations and separations of layers or levels.

Therefore, I suggest to turn to a much more messy but perhaps more realistic and thereby more powerful perspective. The idea is to find a model, or models, which is, or are, structured to address the reality of legal relations and adapted to the complexity of EU public law arrangements. This makes a look at EU public law from an administrative perspective seem to be a rewarding exercise, albeit one significantly different from the early perception of the nineteen fifties. Such an administrative law perspective paints a rather different picture from a more 'traditional' constitutional perspective on EU public law.

One difficulty, though, in adopting an administrative perspective on EU public law lies in finding a workable definition of 'administrative'. European administrative law has grown and evolved becoming an important, yet often not very fully understood, factor shaping the reality of policy implementation in the EU. For the purpose of argument, I propose to define EU administra-

3 M. P. Chiti, Forms of European Administrative Action, 68 Law and Contemporary Problems [2004], 37-60.

4 Implementation on the European level through direct administration was under this model the exception to indirect administration by the Member States. This model is often referred to as 'executive federalism'. See for the description of the classic model of executive federalism e.g. K. Lenaerts, Some Reflections on the Separation of Powers in the European Community, 28 CMLRev [I99I], II-35 at II et seq.; B. Dubey, Administration indirecte et fédéralisme d'exécution en Europe, [2003] CDE, 87-I33. For a view, which emphasises the co-operative nature of executive federalism. see e.g. P. Dann, European Parliament and Executive Federalism: Approaching a Parliament in a Semi-Parliament Democracy', II European Law Journal [2003] 549-574. 
tive law by reference to three broad elements, namely 'functional', 'organisational' and 'procedural'.

The functional aspect of administration addresses the totality of the tasks of administrative actors, no matter who undertakes them and how they are conducted. In the EU, administrative functions consist of a vast array of activities, geared towards fulfilling EU policy objectives. ${ }^{6}$ Functions range from single case decisions and preparatory acts thereof, at one end of the spectrum, to the creation of delegated legislation and the amendment of basic acts and their enforcement, at the other end. They thereby cover a wide range of activities going far beyond the merely technical regulation of the internal market.7 Closely related to the functional dimension of

5 This definitional approach is used here instead of the more common distinction between administrative/technical matters on one hand and political matters on the other. The approach here recommends itself due to the fact that, in the EU, administrative functions in fact often have a distinctly political character. This has a reason not least in the dearth of political in the sense of a party political policy-debate-centred culture on the level of rule-making procedures in the EU and a pre-dominance of expert driven and consensus models. This however also indicates that administrations need to be held and can be held accountable on their own account beyond classical parliamentary, hierarchic Weberian-style models.

6 EU administrative law thus contains rules and principles governing the exercise of administrative functions with relation to the creation and implementation of EU law. There is, however, a remarkable lack of specification of administrative tasks in the founding treaties from which the functional tasks can rather be deduced rather than merely illustrated. Treaty norms more specifically concerning administrative powers can be found in certain policy areas such as those on agriculture, antitrust, state aid and monetary policy. Some general provisions can be found in the delegation provisions in Articles 289, 290 and 29I TFEU (Article 202 third indent and Article 2II EC).

7 The tasks therefore include inter alia planning of joint actions and framework plans (such as for example in environmental law the flora fauna habitat plans, or the ozone plans or even more complex, the setting up of pollution rights under certain trading schemes for pollution). They also include regulatory activities such as administrative rule-making with an effect to the outside. Equally administrative rule-making amounts to the interpretation and further specification of conditions for implementation of legislative provisions. Administrative tasks also encompass taking of single case decisions (such as for example with respect to merger control, anti-dumping measures, the compatibitity of state aid provisions with the common market, the legality of certain business arrangements in light of Articles $8 \mathrm{I}$ and $82 \mathrm{EC}$ ). They further include making of recommendations, opinions and reports (where so required by legislation or where there is a legal basis to do so) as well as coordination and supervision of private actors involved in administrative activities such as standard setting and normatisation. Coordination tasks also extend to coordination of networks of administration for implementation of EU policies (often found in the context of risk regulation such as for example in the networks created around the marine safety agency. It is also an activ- 
administration, are also organisational and procedural dimensions. From an organisational perspective, there is a great complexity of actors and actorconstellations involved in exercising the administrative function of implementing EU law. Many administrative tasks are fulfilled by Member States' institutions and bodies which, in exercise of these tasks, enjoy limited institutional or procedural autonomy. ${ }^{8}$ When exercised on the European level, executive authority is spread across several institutions, most notably the Commission and the Council, 9 which are now increasingly supported

ity which plays an increasing role in the grey zone between the pillars of the EU such as immigration and border security. It finally is an activity which plays a role in the context of international regulatory cooperation towards actors outside the EU). Administrations also fulfil supervisory functions (as for example the supervision by the Commission of Member State implementing measures or spending decisions of EU funds). In certain cases they also include redistributive disbursement of funds (for example in the area of distribution of subsidies for agriculture, research or development aid and emergency aid). This often takes place in cooperation between EU actors as well as public and private actors in the Member States. Important are further information management (for example in the form of publication of data as well as the establishment and sharing of data in common data networks or through mutual assistance arrangements).

8 See originally formulated in Case 33/76 Rewe-Zentralfinanz EG v. Landwirtschafts-Kammer für das Saarland [1976] ECR I989, para 5. Limitations of the Member States' autonomy arise from the fact that Member States' substantive and procedural administrative law is applicable only within the framework of EU/EC law. The framework is set by basically three factors. First, Member States substantive and procedural law is applicable only in the absence of any explicit provisions of Community law requiring the adoption of either specific procedures or institutional organization of the Member States administrative structures. Second, the application of procedural rules of Member States for application of Community law needs to be exercised in strict compliance with the principles of equivalence and effectiveness. The principle of equivalence requires that national arrangements for the implementation of Community law 'are not less favourable than those governing similar domestic actions' and the principle of effectiveness requires that the Member States' arrangements 'do not render practically impossible or excessively difficult the exercise of rights conferred by Community law.' See: Case C-26I/95 Palmisani [I997] ECR I-4025, para 27; C-453/99 Courage [200I] ECR I-6297, para 25.

9 It is important to note that due to the former pillar structure of the EU, not only the Commission, traditionally the centre of the European-level executive, but also the Council and specifically its General Secretariat with the help of Council working parties and cocoordinating committees were developing as an executive centre for certain policy areas. Beyond the traditional possibility of retaining certain executive decisions under Article 202 third indent EC, the latter developed and increasingly implemented policies to implement joint positions and action plans in the areas of the CFSP and CJHA matters. But also in the areas of the EMU, the Council's Eurogroup had created important administrative tasks for the Council. See for an overview e.g. T. Christiansen and S. Vanhoonacker, At a Critical 
by EU agencies. Further, executive functions exercised on the EU level are almost always undertaken in cooperation with administrative actors from the Member States and private parties, and in some policy areas within networks which included participants from outside the EU.

The organisational separation between EU and Member State administration, however, does not stand in the way of forms of procedural cooperation. Such cooperation of organizationally separate actors carrying out administrative functions leads often to a network structure involving a diversity of actors. ${ }^{10}$ Most forms of procedural cooperation of this kind are based on information exchange and the joint gathering and/or generation of information. ${ }^{\text {II }}$ Such procedures vary according to the level of detail the subject of a regulatory administrative measure, for example, depending upon whether it will result in administrative rule-making or single case decision making. Such procedures also vary considerably from one policy area to another. ${ }^{\mathrm{I} 2}$ Procedural cooperation leads increasingly to joint planning networks for which EU law provides the framework of the actions of the Commission (and sometimes European agencies) together with national

Juncture? Change and Continuity in the Institutional Development of the Council Secretariat, 3I West European Politics [2008] 75I-770.

Io Structures to coordinate actors include comitology committees for development and coordination of implementation of EU law between Member States and the Commission, as well as agencies fulfilling special tasks of network administration.

II In practice, these forms of cooperation consist of obligations of different intensity. They can consist of either ad-hoc or a permanent exchanges. Ad-hoc single case related cooperation is mainly to be found in areas where information is gathered and exchanged through mutual assistance requirements or systematized reporting duties. Exchange takes place vertically and horizontally between the Commission and national as well as European agencies. See e.g. the 'European Regulators Group' in the telecommunications sector (Decision 2002/627), the 'Committee of European Securities Regulators' in the financial services sector (Decision 200I/527 [200I] OJ LigI/43) and the 'European Competition Network' (Council Regulation I/2003 [2003] OJ LI/I). Forms of complex administrative cooperation exist with composite procedures (see e.g. H.C.H. Hofmann, Decision Making in EU Administrative Law - The Problem of Composite Procedures, I5 Administrative Law Review [2009] (forthcoming)).

I2 Information networks have been established to channel and to co-ordinate the generation and editing of data relevant to administrative activity. A prominent example of such a network is the 'European Information Observation Network,' Eionet (Council Regulation I2IO/90 of 7 May I990, OJ I990 L I20/I and Council Regulation 933/99 of 29 April I999, OJ I999 L II7/I, amending Regulation I2I0/90 on the establishment of the European Environment Agency and the European environment information and observation network) of public and private actors 'record, collate and assess data on the state of the environment, to draw up expert reports (...), to provide uniform assessment criteria for environmental data to be applied in all Member States.' 
authorities. ${ }^{13}$ Similar developments exist with respect to so called 'enforcement networks'. ${ }^{14}$ An array of formal and informal governance structures exist in the implementation process for co-ordinating measures of Member States or actions between the European and the national level within these networks. ${ }^{15}$ Such network structures cannot be well understood if considered only from the standpoint of the organisational separation of, on one hand, the EU and, on the other, a Member State as unitary actors with apparently competing competences.

This short tour d'horizon of EU administrative law implies the need to establish realistic, systematic legal thinking about the multi-dimensional nature of a system which combines the particularities of the functional unity of administrative tasks undertaken by actors separated organisationally (or perhaps structurally) but engaged in often intense procedural cooperation.

I3 The TFEU provides for certain planning competencies in areas such as infrastructure, environment, research support, economic and social cohesion or agriculture and fisheries policies - to name just a few. The result of all of these planning procedures is that is no planning takes place purely on a European level. Instead, Member State authorities always participate in the creation and implementation as well as updating of planning activities. The coordination of the Member State and the European level takes place through comitology procedures, often in addition to a structure of formalised contacts between the agencies involved in the different phases of planning procedures. The European Structural funds are an exemplary model of coordinated planning structures. Their implementation is characterized by the principle of complementing measures and partnership between different local, regional and national actors from the Member States level and the European level as well private participants (See Council Regulation (EC) No I260/1999 of 21 June I999 laying down general provisions on the Structural Funds, OJ I999 L I6I/I).

I4 Examples of the use of network structures with both vertical and horizontal relations have increased in recent years. The most publicised example is the modernisation of the enforcement regime for EU competition law under Articles IOI and IO2 TFEU (Articles 8I and 82 EC) in Regulation I/2003, which has ended the Commission's monopoly of granting individual exemptions and entrusts the enforcement of the Community's antitrust rules to the Commission, national competition authorities and national courts. This parallel form of enforcement requires a high degree of co-ordination, which is pursued within the European Competition Network linking the Commission and national competition authorities. Similarly, under the telecommunications 'framework directive' (Directive 2002/2I of the European Parliament and of the Council, [2002] OJ I08/33) an organisational structure is established in which the national regulators are integrated into a unitary administrative structure for the enforcement of Community rules. In addition, the Commission set up a 'European Regulators Group for Electronic Communications Networks and Services' to provide 'an interface between national regulatory authorities and the Commission' (Commission Decision 2002/627, [2002] OJ L 200/38).

I5 See e.g. T. Christiansen and S. Piattoni, Informal Governance in the European Union, Elgar Publishing (Cheltenham 2003). 
The intense procedural cooperation in turn often leads to the creation of new organisational forms. ${ }^{16}$

\section{Challenges from an Administrative Law Perspective}

It is especially these particularities of EU administrative law that provoke some of the most significant challenges for future development of EU public law. Some of these I will briefly outline in the following considerations which I personally find the currently the most challenging.

In the following, I list seven challenges for EU public law arising from those developments. ${ }^{17}$ I submit that the EU public lawyers need to address these in order to contribute to an improvement in the state of law and governance in the EU. These seven factors are of course not the only ones. But they are definitely challenges which would benefit from a more in-depth and probably also comparative analysis.

\section{I Allocation of Responsibilities in the EU Administrative Networks}

What might be identified as a first challenge to EU public law from an administrative perspective is the need to develop a proper understanding of the realities of organisational separation and procedural cooperation within the networks of actors undertaking administrative functions. Achieving such an understanding is no easy feat, for a number of reasons. One reason is that network architectures are generally policy-specific. In the EU there is, so far, no general approach spanning various policy areas. The various types of information, enforcement and planning networks in different policy areas link the administrations of the Member States directly with agencies, the Commission and Council. Therefore, any allocation of

I6 For example, the European Agency for the Evaluation of Medicinal Products (EMEA, established by Council Regulation 2309/93, [I993] OJ 2I4/I) is charged with the co-ordination and provision of scientific expertise in the field of medicinal products. Its task is part of an administrative process, namely the authorisation of medicinal products, as its Committees for Proprietal Medicinal Products and the Committee for Veterinary Medicinal Products provide scientific opinions, on the basis of which the Commission takes the final decision. The agency has been established on the basis of these committees which prior to the creation of the agency were established under comitology

${ }^{17}$ It is entirely up to the reader, if he or she so wishes, to associate the seven challenges outlined in this paper with either the seven virtues (chastity, temperance, charity, diligence, kindness, patience, and humility) or the seven sins (lust, gluttony, greed, sloth, wrath, envy, and pride). 
responsibilities needs to acknowledge that it takes place in the context of a highly integrated system. Specifically, this means that Member States and the Union as such only exceptionally interact through hierarchical chains, links or contacts, for example channelled through governments. Instead, interactions take place and responsibilities are allocated and satisfied in the context of direct links between EU actors and their Member State counterparts together with semi-private and private actors. ${ }^{18}$ Thus, as actors within the Union context, the Member States are 'disaggregated'. ${ }^{19}$ This is neither negative nor astonishing in a system of shared sovereignty. ${ }^{20}$ It requires however, careful analysis of exactly where decisions are taken and thus where responsibility ultimately lies. ${ }^{2 \mathrm{I}}$

The challenge arising from such an assessment is to allocate responsibilities. This involves 'mapping the locus' of executive (and by contrast also legislative) powers not only with respect to the production of formal EU/EC legal acts but also within the (often informal) forms of network coopera-

I8 The advantage of hierarchical systems is that responsibilities and control structures are more easily attributed to single actors: The disadvantage lies in problems with the flow of information and the system's lack of flexibility. Both advantages and disadvantages of hierarchical systems are much less pronounced in Europe's integrated administration, where the Member State and Community administrative action are through procedures extremely integrated.

I9 A.-M. Slaughter, A New World Order, Princeton University Press (Princeton 2004), pp. 5, I2. Slaughter, uses this phrase for calling for a conceptual shift in understanding states in the international sphere. She asks to 'Stop imagining the international system as a system of states-unitary entities like billiard balls or black boxes-subject to rules created by international institutions that are apart from, 'above' these states. Start thinking about a world of governments - legislation, adjudication, implementation - interacting both with each other domestically and also with their foreign and supranational counterparts.' Her concept is all the more applicable in the context of the supranational EU.

${ }^{20}$ The evolving reality of integrated administration thus is the story of the development of a system of decentralised yet cooperative administrative structures. This development has transformed both the European as well as the national legal systems. National administrations had developed under national public law as state-specific structures. These reflected different identities, historic traditions of organisation and certain underlying values such as regionalisation or centralised unification within a state. The effect of European integration has been to open Member States public law systems obliging them to develop administrative institutions, bodies and procedures required for an effective exercise of shared sovereignty under the system of EU law.

${ }^{2 I}$ F. Bignami, Foreword, 68 Law and Contemporary Problems [2004] I-20 thus observed that decision-making in these contexts is 'national, transnational, and supranational, all at the same time.' 
tion. ${ }^{22}$ That requires recognising the reality of the forms of EU law which have been created in and around those forms which are formally provided for or acknowledged in the Treaties. It also requires an understanding of the intricacies of the forms employed in the exercise of executive powers in the EU. Such understanding is also a pre-condition of designing effective accountability mechanisms tailored to fit contemporary Union reality.

The challenge is, therefore, to comprehend the numerous and varied structures of governance and to make them transparent in order to permit the effective allocation of indeed political, but especially legal, responsibility. Doing so is an essential condition of establishing subsequent supervision and achieving accountability of administrative action, a condition for adhering to the rule of law in the exercise of public power. This task is not made easy by the diversity in the types of actors and the forms of cooperation in existence, including for example the role of private parties in co-regulation and rule-making. The satisfaction of this task further needs to take into account that, unlike many forms of organisation in 'traditional' administrative law, hierarchical structures of control and supervision are not generally an organisational feature within the network arrangements referred to here.

\subsection{Establishing a Coherent Approach to Delegation of Implementing Powers}

A second challenge facing EU public law from an administrative perspective is linked to the first dealing with allocation and delegation of powers. It addresses two questions. One is which types of act are available the public administration, especially after the entry into force of the Treaty of Lisbon. The other is how to deal with comitology and agencies in this context.

With respect to the first aspect of the types of act, a wide variety of types of action in the form of both hard and soft law has been created in practice. It considers all types of act formally provided for in Article 288 TFEU (and formerly Article 249 EC) but also a great amount of atypical types of act. These types of act fulfil traditional legislative tasks but also help pursuing goals such as planning, network cooperation and others more. The procedures leading to the adoption of an act can be formal and informal; acts can be preparatory or final. The addressees of the acts can be both public and private actors.

The Treaty of Lisbon was originally designed as an attempt to simplify the typology of acts. It provides that legislative acts (being the outcome of a legislative co-decision procedure resulting in regulations, directives and decisions). Delegation of legislative powers to issue delegated acts 'to supplement

${ }^{22}$ D. Curtin, 'European Legal Integration: Paradise Lost?’ in: D. Curtin, A. Klip, J. Smits, J. McCahery (eds.) European Integration and Law, Intersentia (Antwerpen 2006), I-54, at p. 35 . 
or amend certain non-essential elements of the legislative act'23 and delegation of implementing powers 'where uniform conditions for implementing legally binding Union acts are needed'24 is possible under Article 288-29I TFEU. Delegated and implementing regulations can be issued as directives or decisions. Therefore, the Treaty of Lisbon provides for three types of legislative acts and six different categories of formally non-legislative acts (regulations, directives and decisions issued as either delegated or implementing acts). This supposed 'simplification' is also problematic from the point of view of containing only unilateral types of act. In reality, and to an increasing extent, administrative action also takes place through non-unilateral types of acts by way of multilateral agreements between various kinds of actors - both public and private - from the European and the national levels. Contractual - or at least consensual or negotiated - relations are at the core of the emerging administrative network used for implementing EU policies. ${ }^{25}$ Agreements are, for example, used widely in non-hierarchical network relations. Other than the instrument of inter-institutional agreements (Article 296 TFEU) and international agreements (Article 2I6 TFEU), agreements as types of administrative acts themselves are acknowledged (as was the case under the EC Treaty) only indirectly, for example in provisions on Court responsibilities. ${ }^{26}$

With respect to the other issue, it is important in this context to reflect on the new typology of acts influence the future of comitology and the role of agencies. For example, one of the central differences between the separate categories of delegated acts and implementing acts under the Treaty of Lisbon is the mode of supervising the Commission with respect to delegated matters. ${ }^{27}$ In the case of delegated acts, the EP and Council can reserve the right either to revoke the delegation or to object to a proposed measure. Implementing acts would, on the other hand, be subject to newly defined comitology rules. ${ }^{28}$ The world of EU agencies, however, remain largely

23 Article 290 TFEU.

${ }^{24}$ These are defined in Article 29I TFEU as acts for cases

25 See H.C.H. Hofmann, Agreements in EU Law, 31 European Law Review [2006], 800-820.

${ }^{26}$ See Articles 272 and 340 TFEU.

27 There are however hidden delegation issues. One is the possibility of sub-delegation is an additional result of the distinction between the two categories of delegated and implementing acts in Articles 290 and 29I FEU. This possibility will arise especially in areas of broad delegation of legislative powers to the Commission under Article 290 FEU. The Commission may then be obliged (under Article 29I FEU) to sub-delegate to itself implementing powers. This combination of provisions may thus result in a cascade of delegation of powers.

${ }^{28}$ Supervision of implementing powers delegated to the Commission with the help of Comitology procedures has also to date been one of the major sources of inter-institutional conflict. The differences of Articles 290 and 29I TFEU with respect to political supervision 
untouched by the new types of act - essentially ignored by the framers of the Lisbon Treaty. There is thus a continuously growing gap between the prolific creation of agencies in the EU and the conferral of powers to them on one hand, and their recognition in EU primary treaty law on the other hand. ${ }^{29}$ As a consequence, agencies, despite being mentioned as potential sources of reviewable final acts in Article $2 \sigma_{3}$ (I) last sentence TFEU are not expressly mentioned as recipients of delegated powers for the issue of implementing acts. Such a delegation is explicitly reserved to the Commission or, exceptionally, to the Council, despite the existence of legislation which already increasingly transfers functions directly to agencies without the intermediary of the European Commission..$^{\circ}$ With the absence of express reference to the delegation of powers to agencies, the Treaty of Lisbon (as well as already provided for in the Constitutional Treaty) reiterates the effect the Meroni doctrine has in written primary law, ${ }^{31}$ despite the fact that the ECJ has itself incrementally moved away from the doctrine in its more recent case law,

of delegated and implementing acts can be interpreted as a between-the-lines commentary on the underlying developments of Europe's increasingly integrating administration.

29 D.Curtin, Delegation to Non-Majoritarian Agencies and Emerging Practices of Public Accountability, in: D. Geradin, R. Munoz and N. Petit (eds.), Regulation through agencies in the EU Elgar, (Cheltenham 2005), 88-II9; D. Fischer-Appelt, Agenturen der Europäischen Gemeinschaft, Duncker und Humblot (Berlin I999) 87-II7.

30 Examples for agencies which have received legislative delegation for single case and restricted regulatory decision-making powers are the Office for the Harmonisation of the Internal Market (OHIM) which is empowered to take legally binding decisions on the registration of Community trade marks and other Intellectual Property rights (see Article 43 (5) and 45 (6) of the Council Regulation 40/94 of 20 December 1993 (OJ I994 L II/I) on the Community trademark (as amended in OJ I994 L 349/I, OJ I995 L 303/I). The Community Plant Variety Office (CPVO) has been delegated the power to adopt legally binding decisions in relation on the registration of plant variety rights (Article 62 Council Regulation 2100/94 of 22 July I994 on Community plant varieties, OJ I994 L 227/I amended in OJ I995 L 258/I). Powers akin to regulatory powers have been granted to the European Air Safety Agency (EASA) to adopt decisions with regard to criteria for type certification and continued airworthiness of products, parts and appliances, and the environmental approval of products (Regulation (EC) I592/2002 of the European Parliament and of the Council of I5 July 2002 on common rules in the field of civil aviation and establishing a European Aviation Safety Agency, OJ 2002 L 240/I)

3I In Meroni (Cases 9 and 10/56 Meroni v High Authority [I957/58] ECR I33), the ECJ had considered as unlawful the delegation of discretionary powers to a private body containing the authorisation to take discretionary decisions which went beyond the delegation to clearly defined powers. See for a discussion of these agency related problems E. Chiti, Decentralisation and Integration in the Community Administration: A New Perspective on European Agencies, to European Law Journal (2004) 402-438; P. Craig, EU Administrative Law Oxford University Press (Oxford 2006) I60-I64 and I84; M. Everson, Independent 
based on the view that Meroni dealt only with a delegation of powers to a private body. As a consequence, the division between the constitutional provisions and the requirements of the architecture of the emerging European networked administration, including European agencies, will increase. Despite all this, delegation questions will inevitably continue to arise.

Further, the questions of delegation and of the types of act in the context of administrative activity also need to take into account executive cooperation which does result in final acts reviewable before Court. The various methods of governance often summarised as OMC (Open Method of Cooperation) are a case in point. The application of general principles of $\mathrm{EU}$ law to such methods in order to establish procedural guidelines and protect rights of parties involved provides a possible way of proceeding. Difficulties would arise with their enforcement though. The more informal a procedure, the less transparent and subject to control and review mechanisms it generally is.

These few examples show that the challenge of establishing a coherent approach to the delegation of implementing powers and to the procedures under which delegations can be made, as well as the potential for uncertain or unsatisfactory outcomes remains important, complex and far from settled. Attempts in the Treaties intended to simplify the issue leave us not only with a complex array of types of acts and procedures, they also address neither the issue of integrated administration nor that of administrative action in forms other than unilateral acts.

\subsection{Reinforcing Accountability in Administrative Networks}

Yet a third challenge for EU public law is the aspect of accountability of the actors involved in the administrative networks mentioned already. Accountability has both a political and a legal dimension..$^{32}$ Greatly simplified, the political dimension concerns attempts to ensure that the political will prevails while the legal dimension focuses on the issue of compliance with the rule of law in a broad sense, including legally defined structural and substantive elements. ${ }^{33}$ Both the legal and political dimensions of accountability can be established by both ex post and ex ante mecha-

Agencies: Hierarchy Beaters?, 2 European Law Journal (1995) I80-204; M. Koch, Die Externalisierungspolitik der Kommission, Nomos (Baden-Baden 2004).

${ }^{2}$ M. Bovens, Analysing and Assessing Accountability: A conceptual framework, I3 European Law Journal [2007], 447-468.

33 I.e. the principles of requirement of a legal basis, excluding ultra-vires activity and all activity violating fundamental rights and fundamental principles including the principles of good administration. This definition, as the further development of the ECJ's famous definition of the Community as a 'Community based on the rule of law' in Les Verts (Case 294/83 Les Verts [I986] ECR I339, para 23). Among other goals, this approach is aimed at 
nisms. Ex ante mechanisms broadly allow for the defining of tasks and for imposing conditions for carrying them out. They also include matters such as the choice of personnel entrusted with the tasks and the allocation of the budget for the purpose. For example, ex ante supervision within the public administration itself (administrative supervision of the administration) includes the structuring of decision-making processes in advance, the provision of information and interpretive assistance generally, guidance and advice in specific cases and measures which are in fact designed to ensure particular outcomes or at least outcomes within a particular range of possibilities. Ex post mechanisms provide inter alia for possible demands to justify actions already taken, as well as rewards for compliance or sanctions for non-compliance with the definitions of task and limits set ex ante. ${ }^{34}$ In that regard, accountability structures need to include a proper mix of ex ante and ex post administrative, political and judicial supervision and control. In order to be effective they need to include channels allowing input from individuals and civil society groups in order to set accountability mechanisms in motion.

In EU law, many different approaches to accountability mechanisms for network administration exist. The various structures of European agencies are, in fact, a perfect example of an experimental approach to the design of forms of accountability. These include: reporting obligations to the EP and Council; appointment and budgetary controls; and regular subjection of agencies to external review and evaluation. The latter are themselves intended to also take into account views of parties with an interest in the functioning of the agency. The means of achieving accountability are also comprised of internal complaint mechanisms designed for self-review of decisions such as boards of appeal. Others take the form of a sort of administrative control agency for certain types of matters, such as violations of individual rights. These include the matter of data secrecy through an independent European Data Protection Supervisor (EDPS) and financial responsibility through OLAF (the Commission's Office pour la lutte anti-fraude). These two have the right to intervene directly in on-going procedures, thus not requiring a control only ex post a final decision.

securing individual freedoms and rights within a system allowing for proper exercise of public power.

34 M. Bovens, Analysing and Assessing Accountability: A conceptual framework, I3 European Law Journal [2007], 447-468. The ECJ links this notion with the requirement to guarantee an institutional balance stating in case C-70/88 Parliament v Council [I990] ECR I-204I, para 22 that ' $[\mathrm{o}]$ bservance of the institutional balance(...) requires that it should be possible to penalize any breach of that rule which may occur.' The relation between these two actors can be hierarchic or can exist within networks. Ex ante and ex post functions may themselves be delegated and sub-delegated. 
When analysing the various accountability mechanisms which have been created in different contexts of network administration it should, however, not be forgotten that openness and transparency are key elements of the procedures. This allows for awareness of the criteria and access to the material taken into account by actors within administrative networks and the allocation of competences for individual steps for which the relevant actors will be held responsible. This is inter alia a key condition also for public scrutiny of, and participation in, the exercise of public power.

Developing a set of accountability mechanisms which can be applied generally as part of a transparent and visible system of control and supervision of network administration is one of the central challenges for EU administrative law in the future.

\subsection{General Procedural Rules for EU Administration?}

This leads to a fourth challenge of EU administrative law: It can be asked whether a general set of administrative rules and principles applicable throughout the EU system could plausibly be established. Such a development could prove useful especially in the light of the lack of transparency, the diverse methodologies of accountability and generally the fluidity of EU administrative law techniques and structures. In fact, much of the EU's administrative structures and administrative law are in a permanent state of development. Each separate policy area is, in effect, a field of experiment. Moreover, the law is forever attempting to catch up with changing administrative reality, a feature EU administrative law shares with virtually any other area of law but one shared especially with national administrative law. 35 In addition to this liability, there is very little coordination between the policy areas. Very few provisions and mechanisms exist in EU law which are applicable throughout the full range of policy areas, most being policy-specific. Amongst the few legal norms of general application are the Comitology Decision, ${ }^{36}$ Directives on data protection, ${ }^{37}$ the Financial Regulation, ${ }^{38}$ the

35 F. Bignami, Foreword, 68 Law and Contemporary Problems [2004] I-20.

${ }^{36}$ Council Decision 87/373/EEC of I3 July I987 laying down the procedures for the exercise of implementing powers conferred on the Commission, [1987] OJ L I97/33 and Council Decision I999/468/EC laying down the procedures for the exercise of implementing powers conferred on the Commission, [I999] OJ L I84/23. Decision 2006/5I2/EC, OJ 2006 L/II. For a discussion of this pre-2006 development, see C.F Bergström, Comitology: Delegation of Powers in the European Union and the Committee System (OUP, 2005).

37 Regulation 45/200I of the European Parliament and of the Council of I8 December 2000 on the protection of individuals with regard to the processing of personal data by the Community institutions and bodies and on the free movement of such data, OJ 200I L 8/1.

38 Council Regulation $1605 / 2002$ of 25 June 2002 on the Financial Regulation Applicable to the General Budget of the European Communities, OJ 2002 L 248/I which replaced the 
Regulation on so called Community 'executive agencies'39 as well as Directives on access to information. ${ }^{40}$ Additional sources of general EU administrative law arise from general principles of law $^{4 \mathrm{I}}$ and fundamental rights, ${ }^{42}$ which apply within the sphere of EU law irrespective of the specific law applicable to the procedure, whether national or European.

However, such general EU administrative law, except for the Comitology Decision, generally does not establish any specific procedural rules on supervision and review. Policy specific law generally leaves it to the Member States to establish the procedure as well as the conditions for supervision and judicial control of administrative action. The founding treaties did not provide for a legal framework for such an integration of administrative procedures and mechanisms. It has been due to the evolutionary and diversified development of the forms of integrated administration that has led to many new and unforeseen legal problems which, as noted above, often result from non-hierarchical, network-like structures and cooperative procedures for administration in the EU.

One of the striking features of this development is that the evolution of integrated administration has not been subject to any systematic approach, whether through hard or soft law. There is no standard EU 'administrative procedure act' or similar code or legal framework horizontally applicable

I977 Financial Regulation (OJ I977 L 356/1).

39 Council Regulation 58/2003 of I9 December 2002 laying down the statute for executive agencies to be entrusted with certain tasks in the management of Community programmes, OJ $2003 \mathrm{~L} \mathrm{II/I.}$

40 See for the EC, Regulation I049/200I of the European Parliament and of the Council of 30 May 200I regarding public access to European Parliament, Council and Commission documents, OJ 200I L I45/43.

4I General principles of law often include principles requiring standards of procedural justice in administrative procedures, such as the notions of proportionality, rights of defence and others. See for an overview: J. Schwarze Europäisches Verwaltungsrecht 2nd edition, Nomos (Baden-Baden 2005); T. Tridimas General Principles of EU Law 2nd edition, Oxford University Press (Oxford 2006); J. Jans, de Lange, S. Prechal, R. Widdershoven Europeanisation of Public Law Europa Law Publishing (Groningen 2007).

${ }^{42}$ Fundamental rights can be procedural, as Article 4I of the Charter of Fundamental Rights of the EU shows or substantive. All provisions which regulate activity within the scope of Community law need to be interpreted in the light of fundamental rights guaranteed by the Community legal order. Generally see Case C-I59/90 Society for the Protection of Unborn Children Ireland [1991] ECR I-4685, para 3I; Case C-299/95 Friedrich Kremzow v Austria [I997] ECR I-2629, para I5; Case C-276/or Steffensen [2003] ECR I-3735, para 70. The definition of the scope of Community law is widely defined in Case C-260/89, ERT-AEv DEP [I99I] ECR I-2925, paras 42, 43. 
throughout the policy areas touched by European integration. ${ }^{43}$ Also, the doctrinal treatment of these matters of general EU administrative law is in its infancy. Only recently has there been a developing interest in research with respect to a more general approach to EU administrative law going beyond studying merely the general principles of law. ${ }^{44}$

\subsection{Composite Procedures}

A fifth feature, bringing its own challenges, is that EU administrative law is in many important ways distinct from its national counterparts, most notably through the development of multiple forms of 'composite procedures.' Composite procedures are multiple-step procedures with input from administrative actors from different jurisdictions. These cooperate either vertically (between EU institutions and bodies, on one hand, and Member States' institutions and bodies, on the other), horizontally (between various Member State institutions and bodies) or in triangular procedures (in which institutions from various Member States' as well as EU institutions and bodies are involved). The final acts or decisions emanating from such procedures are issued by a Member State body or an EU institution or body. ${ }^{45}$

Such composite procedures are made increasingly necessary by the complexity of regulatory demands, which often exceed the limits of competence of individual regulatory levels and individual Member States. The emergence of composite procedures involving vertical and horizontal administrative cooperation gives rise to many legal problems, especially for the protection of rights and the supervision of administrative action. ${ }^{46}$

43 There is of course legitimate debate as to whether there is to date a legal basis for such an approach. Article 298 II TFEU would arguably create such a legal basis for a generalisable EU administrative law for implementation by EU institutions and bodies.

44 J.-B. Auby, J. Dutheil de la Rochere (eds.) Droit Administratif Européen Bruylandt (Bruxelles 2007); M. P. Chiti, G. Greco (eds.) Trattato di diritto amministrativo comunitario Vol. I, II, Giuffrè, 2nd ed. (Milano 2007); P. Craig EU Administrative Law Oxford University Press (Oxford 2006); H.C.H. Hofmann, A. Türk (eds.), EU Administrative Governance, Elgar Publishing (Cheltenham 2006); E. Schmidt-Assmann, B. Schöndorf-Haubold (eds.) Der Europäische Verwaltungsverbund Mohr (Tübingen 2005).

45 The final decision, when issued by a Member State administration will often have 'transterritorial' effect, which have an effect beyond the territory of the issuing jurisdiction. See: H.C.H. Hofmann, Decision-Making in EU Administrative Law - The Problem of Composite Procedures, 6r Administrative Law Review [2009 special edition] 199-221.

${ }^{4}$ D. Curtin, Holding (Quasi-)Autonomous EU Administrative Actors to Public Account, I3 European Law Journal [2007], 523-54I, at 540: 'One of the main problems regarding the checks and balances under construction in the 'undergrowth' of legal and institutional practice is the chronic lack of transparency of the overall system. It is not that there is 
Appropriate solutions to these problems might include the construction of a control network, that is, a network of accountability and supervision including particularly the control of legality, maybe even a curial network. 47 This seems especially necessary in the EU legal system, in which harmonisation of procedural law is undertaken not systematically but in bits and pieces throughout the highly diverse regulation of various substantive law provisions.

\subsection{Establishment and Use of Information}

Sixthly, in EU administrative law, information including its establishment and use, increasingly needs to be treated as an important topos of concern, and thus of legal research, in its own right. The reason is that the sophisticated complexity which EU administrative co-operation within networks has reached is based mainly on the generation, gathering, compilation, handling, computation, management and distribution of information. Increasingly, information is the key input and commodity for decision-making through administrative cooperation in the EU. Composite procedures, referred to above, can themselves generally be reduced to steps, measures and decisions concerning the joint creation, use and sharing of information. Information is used in relation to many functions inter alia as a raw material for public decision-making, planning and steering activities. One of the central reasons for the importance of information in its own right is that the law concerning the establishing, compiling and use of information is developing at an increasingly rapid pace in numerous policy areas, reflecting the nature, role, technological handling, economic, social and political relevance of information in practice. Next to policy-specific rules such as in areas of risk regulation, obviously general legal provisions can be found on access to data and on data protection. However, European criminal law, EU security policy, border protection and anti-terrorism measures as well as civil and regulatory law (for example, in the field of insurance) are also fast expanding their reach and range within data-oriented fields.

The nature and the extent of the impact of the role of information and the accompanying developing law of information in the EU on the fundamental rights of the citizens is considerable. There is both a substantive and a procedural element relevant to understanding this aspect of the exercise of public powers in Europe. The substantive element concerns the establishment of joint rules and principles for the creation, exchange and use of information. Substantive rights of participation are necessary to ensure both

no public accountability (...) it is rather that it is not visible and often not structured very clearly.'

47 The concept of a possible network of courts is further discussed below in the following chapter of this paper. 
that individuals do not merely become sources of administrative information, but also that they be treated as individuals holding rights under European law. The procedural element concerns the establishment of rules and principles for composite decision-making in the EU so as to ensure that individuals can actually enforce such participation rights broadly defined. $4^{8}$ These are essential elements for a modern EU legal system in which accountability of the exercise of public powers is guaranteed.

\subsection{The International Setting of EU Administrative Activity}

A seventh feature, linked to the network structure, is the international openness of the EU administrative system. This poses specific challenges to the legal framework of EU administrative activities and essentially the understanding of what the EU itself is and where it and its legal system strictly ends.

EU administration is subject to three basic elements or dimensions of internationalisation. The first element is the internationalisation of regulatory systems. European administrative activity is often the necessary result of obligations arising from international organisations. To these either the Member States are exclusively signatories, or, as it were in some cases of mixed agreements, also the EC (in future the EU) is member. These can be, for example, the UN, 49 the WTO, ${ }^{\circ}$ or other organisations such as the Council of Europe, the ILO, NATO or the OECD. This international dimension adds to the complexity and difficulty of allocating responsibility since impulses for action may emanate from outside of the EU legal system. The second dimension of the internationalisation of EU administrative activities results from the fact that EU administrative networks often include non-EU participants such as third states and international NGOs. Finally, the third

$4^{8}$ See with further detail on conceptual and legal philosophical considerations, see e.g.:

J. Mendes, Participation and participation rights in EU law and governance, in: H.C.H.

Hofmann, A. Türk (eds.) Legal Challenges in EU Administrative Law: The Move to an Inte-

grated Administration, Elgar Publishing (Cheltenham 2009) 257-287; J. Greenwood, Interest representation in the European Union, Palgrave Macmillan (Houndmills, 2003); P. Magnette, European governance and civic participation: beyond elitist citizenship?, 5I Political Studies [2003], I44-I60.

49 See e.g. the increasing police and secret service coordination activity at the UN level resulting in Case T-306/or Ahmed Ali Yusuf [2005] ECR II-3533; C-4I5/05 P and C-415/05 P Kadi and Al Barakaat [2008] ECR I-nyr of 3 Sept. 2008, in which the ECJ followed AG Maduro in providing for judicial review of EU measures implementing UN sanctions against individuals.

50 Especially with respect to enforcing obligations under agreements such as the GATT, GATS, TRIPS, SPS, TBT and SCM as well as panel and appellate body decisions establishing the details of these obligations. 
dimension reflects the fact that not all EU Member States participate in a given policy and thus that cooperation between certain EU members begins or may persist through cooperation initiated through agreements under public international law..$^{\text {I }}$

These three dimensions are another indicator of the non-hierarchical, disaggregated state of administrative networks in the EU. They raise questions parallel to the external policy considerations from the constitutional perspective which need to be dealt with both in the context of 'EU international administrative law' and in what has become known as 'global administrative law.' The network character of administrative cooperation thus surpasses the territorial limits of the EU and its Member States. Such networks often in fact include non-EU actors.

In this respect, EU international administrative law can be said to be completely underdeveloped. Thus far, the EU experience in international administrative law can be seen in a wide range of agreements by the Community and its agencies as well as by the EU. These govern external relations in many policy fields and contain commitments for regulatory cooperation as well as single-case mutual assistance. Many of the activities relate to information gathering and exchange and are thereby highly relevant to the rights of individuals. At the same time, the EC is actively involved in a plethora of international organisations and networks, many charged with administrative tasks. This participation requires the establishment of minimum standards of good administration in order to ensure its legitimacy from the standpoint of the EU/EC own principles.

This situation will not change by an eventual entry into force of the Treaty of Lisbon. In reality international networks play an ever increasing role and yet from the perspective of legal theory they could so far be described as a 'black hole' relying on vague delegations within the legal basis of European agencies, as part of an experimental approach to new forms of governance in the EU. As already in the EU/EC treaties, under the Treaty of Lisbon, the external dimensions of individual policy areas remain largely implicit, relying on implied powers for their legal basis..$^{52}$ What is more, all international agreements are to be concluded following the procedure of

${ }^{5}$ See for example the origins of the Shengen, Dublin and Prüm agreements.

52 M. Cremona, A Constitutional Basis for Effective External Action?, EUI Working Papers Law 2006/30, page I3, para 25, who finds that In relation to energy policy, for example, and transport policy (the area from which AETR doctrine arose and which under the Treaty of Lisbon has been expressly excluded from the scope of common commercial policy), no express provision is made for external powers. The external dimension of energy policy is increasingly important (see for example Council Conclusions of I4 March 2006 on a New Energy Policy for Europe; 'An External Policy to Serve Europe's Energy Interests', paper from Commission/SG/HR for the European Council, Si6o/o6). On the other hand, in relation to environment policy and research and development, also areas of shared competence, 
Article 2I8 TFEU (the slightly amended Article 300 EC)..$^{53}$ No mention is made, however, of international agreements concluded by the EU agencies, such as those used as the basis for information exchange and other cooperation measures.

Given this activity, the achievement of an overarching legal framework is not made simpler by the diversity of conditions within the three pillars of the EU. Especially in the former second and third pillar matters, delegation of powers can be, for example, not only vertical from the Council to an agency but also horizontal involving delegations of powers from Member States directly to agencies. Europol is perhaps the best known example for this type of approach, having been initially set up by the Member States to coordinate certain national police activities. Europol has in recent years concluded an extensive range of international agreements with international organisations and third countries, ${ }^{54}$ but has done so on the basis of a rather shaky legal foundation for such activity. The same tendency, it might be argued, is visible in regard to the more traditional former first pillar matter, for example in respect to the border agency FRONTEX.

\section{Overarching Challenge: Accountability of Networks}

These considerations provide an overview of some important challenges arising from an administrative perspective on EU public law. For a realistic understanding of EU administrative law, one must start by acknowledging the specific contextual factors of functional unity, organizational separation, and procedural cooperation which determine the development of the EU administration. The notion of procedural cooperation has a particular importance in this. In reality such cooperation is often so intensive that the cooperative procedures themselves in effect 'coagulate' so as to become administrative actors. Good examples for this have been comitology committees which have been legislatively transferred to agencies, for example, the European Medicines Agency (EMEA) which evolved out of two comitology committees. The key to the development of a public law framework for administrative action is, then, an understanding of the network-context of administrative law in which actors from various backgrounds, both public and private, cooperate in joint procedures. This network character is also relevant for understanding the difficult distinctions between the European

the conclusion of international agreements is expressly mentioned in the context of international cooperation (Article I9I (4) TFEU).

53 Only with exceptions of some specific additional provisions relating to commercial policy agreements and international agreements in the field of monetary policy.

54 See: http://www.europol.europa.eu/index.asp?page=agreements 
and the international levels in certain administrative procedures, due to many hybrid forms of cooperation. In the wake of this emerge far-reaching questions about the nature of the EU and its limits. Administrative law is a necessary framework for encapsulating and, where possible, generalising the solutions or methods constantly being developed as experimental forms within individual policy areas. A key issue here is the great potential - and great need - for simplification and a more systematic approach. Thus far in legal research, administrative law issues have been addressed mainly in the context of specific policy area-studies such as competition, state aid or regional and structural funds. Attention needs to be given to achieving a more comprehensively applicable law on administrative procedure and organisational form through greater standardization of structures, procedures and methodology throughout the various EU policy fields.

European integration has, therefore, developed over time through the mechanism of a network of integrated executives for the creation and implementation of policies within the sphere of EU law. Rules and principles governing the cooperation itself have often not only been provided for in the Treaties, more often they have simply evolved out of institutional practice. 55 This difference between the formal legal order of the EU and the lived reality can be considered an organisational — or at least conceptual — 'gap.' The gap is one between the reality of the actors involved in creating and implementing EU policies compared with the procedures and institutions as set out (albeit already as complex types of acts and procedures) in the founding Treaties. ${ }^{6}$ The challenge for EU public law theory lies in developing approaches that take into account both the patent and latent realities.

The organisational gap referred to leads also to an 'accountability gap'. The latter arises due to different degrees of integration within European structures of the key elements of what in, a traditional system of separa-

55 Institutional practice, however, does not generally allow deviations from positive provisions in the Treaties. Famously, the ECJ in Case C-25/70 Einfuhr- und Vorratsstelle für Getreide und Futtermittel v Köster [I970] ECR II6I, para 6, the ECJ had relied inter alia on consistent practice of the Community institutions to justify the legality of a comitology procedure. However, in its more recent case law, this reasoning stemming from public international law, has no longer been accepted. In C-I33/06 Parliament v Council (refugee status) of 6 May 2008, [2008] ECR I-nyr, paras 43-63 and C-93/00 Parliament v Council (beeflabeling) [200I] ECR I-IoII9, paras 38-43 the Court stated that long established institutional practice (e.g. the practice to create derived legal bases providing for a different decision-making procedure than that provided in the Treaty to be in violation of the principle of limited attribution of powers under Article 7 (I) EC) was irrelevant.

${ }^{6}$ D. Curtin, Mind the Gap: the Evolving EU Executive and the Constitution, Walter van Gerven Lectures, Europa Law Publishing (Groningen 2004); J. Scott, D. Trubek, Mind the gap: law and new approaches to governance in the European Union, 8 European Law Journal [2002], I-I8. 
tion of powers, would be referred to as the legislative, executive and judicial powers. On the European level, the high degree of integration of executive powers is often not matched by an equal level of integration of legislative and judicial powers. ${ }^{57}$ This leads to imbalances and problems of supervision and control of the executive. It is a consequence which has been deplored with respect to Member State executives: these have been able to become more powerful vis-à-vis their national parliaments due to an escape from political accountability at home through rule-making on the EU level. ${ }^{8}$ This problem has been somewhat addressed by strengthening of the EP and through effective judicial control over the operation of EU law by the ECJ. However, the important difference between an integrated executive and accountability systems is that, on the one hand, there is an integrated executive in which there is close cooperation in agenda setting, policy making and policy implementation. Integration there has become so intense that it is often not possible to discern the locus of responsibility for the final outcome. On the other hand, there is far less integration in the reality of political (parliamentary) and judicial supervision and control of executive actors. This results in structural imbalances in regard to effective accountability. The accountability gap emerges, therefore, between the extent and intensity of executive integration and the capabilities of control over and supervision of the executive actors by other holders of public power.

This has important consequences not only for our understanding of the role of the EU and the Member States but also for the analysis of key aspects of the EU system, in particular the issue of accountability in the exercise of public power in Europe. The latter aspect is arguably the key challenge arising from the (partial) integration I have referred to. The question therefore is whether, in view of the evolution of integrated executives, forms of accountability have been or can be established with equivalent effect. It cannot be treated as a given that such accountability structures would automatically appear in a similar time frame or with comparable speed, not least because the highly integrated network system mentioned has itself developed in a non-coordinated, experimental way, pioneered in individual policy areas.

57 Further explanations in: H.C.H. Hofmann and A. H. Türk, Legal challenges in EU administrative law by the move to an integrated administration, in: Legal Challenges in EU Administrative Law Elgar Publishing (Cheltenham 2009) 355-380.

58 This is generally explained by the fact that conferral of powers from the national to the supranational sphere often affect or even undermine the separation of powers typically established within a state. Since it is generally the executive branch of government representing the state towards the outside, this branch of government gains powers through participation in the exercise of this power on the supranational level which nationally would have remained with the legislature. See with further considerations for the consequences of delegation e.g. D. Sarooshi, International Organisations and their Exercise of Sovereign Powers, Oxford University Press (Oxford 2005) I5. 
The key challenge facing EU public law is thus to align various options of ex ante and ex post modes of control and supervision of executive, parliamentary and judicial character, to ensure both the transparent, controllable and effective exercise of public powers. ${ }^{9}$ Administrative law is an essential and highly important part of public law's toolbox to achieve these goals.

59 Above, it was found that accountability can be considered from three different perspectives aligned to the classical separation of powers as executive supervision, political (parliamentary) supervision and judicial supervision. 
